\title{
Nutrition, Exercise, and Pharmaceutical Therapies for Sarcopenic Obesity
}

\author{
Hidetaka Wakabayashi ${ }^{1, *}$ and Kunihiro Sakuma ${ }^{2}$ \\ ${ }^{1}$ Department of Rehabilitation Medicine, Yokohama City University Medical Center, 1 4-57 Urafune-Chou, \\ Minami ward, Yokohama City, 232-0024, Japan \\ ${ }^{2}$ Research Center for Physical Fitness, Sports and Health, Toyohashi University of Technology, 2 1-1 \\ Hibarigaoka, Tenpaku-Cho, Toyohashi, 441-8580, Japan
}

\begin{abstract}
Sarcopenia is characterized by progressive and generalized loss of skeletal muscle mass and strength, with a risk of adverse outcomes such as physical disability, poor quality of life, and death. Sarcopenic obesity is defined as having both sarcopenia and obesity, a condition reported to be associated with a higher risk for adverse outcomes including functional disability, frailty, poor quality of life, longer hospitalization, and higher mortality rates. The definition and diagnostic criteria for sarcopenia have been described by several working groups on the disease; however, there is no standardized definition and diagnostic criteria for sarcopenic obesity. In this review, we summarize nutrition, exercise, and pharmaceutical therapies for counteracting sarcopenic obesity in humans. Although there are some pharmaceutical therapies for both sarcopenia (i.e., testosterone, growth hormone, ghrelin, and vitamin D) and obesity (orlistat, lorcaserin, phentermine-topiramate, and vitamin D), therapies combining nutrition and exercise remain the first-line choice for preventing and treating sarcopenic obesity. Resistance training combined with supplements containing amino acids are considered most effective for treating sarcopenia. Low-calorie, high-protein diets combined with aerobic exercise and resistance training are recommended for preventing and treating obesity. Therefore, nutrition therapies (low-calorie, high-protein diets, protein and amino acid supplementation) and exercise therapies (resistance training and aerobic exercise) would be expected to be the most effective option for preventing and treating sarcopenic obesity. In cases of severe sarcopenic obesity or failure to achieve muscle gain and weight loss through nutrition and exercise therapies, it is necessary to add pharmaceutical therapies to treat the condition.
\end{abstract}

Keywords: Sarcopenia, overweight, protein, low-calorie diets, resistance training.

\section{INTRODUCTION}

The term sarcopenia was used by Rosenberg to describe an age-related decrease in muscle mass, and originated from the Greek words sarx (flesh) and penia (loss) $[1,2]$. This term was applied initially to denote loss of muscle mass. In 2010, the European Working Group on Sarcopenia in Older People described sarcopenia as a syndrome characterized by progressive and generalized loss of skeletal muscle mass and strength, associated with a risk of adverse outcomes such as physical disability, poor quality of life, and death [3]. In 2011, the International Working Group on Sarcopenia defined the disease as an "ageassociated loss of skeletal muscle mass and function". Sarcopenia is a complex syndrome that is associated with muscle mass loss alone or in conjunction with increased fat mass. The causes of sarcopenia are multi-factorial and can include disuse, changing endocrine function, chronic diseases, inflammation, insulin resistance, and nutritional deficiencies. While cachexia may be a component of sarcopenia, the two conditions are not the same [4]." Decreased muscle

*Address correspondence to this author at the Department of Rehabilitation Medicine, Yokohama City University Medical Center, 4-57 Urafune-chou, Minami ward, Yokohama city, 232-0024, Japan; Tel: +81-45-261-5656;

Fax: +81-45-253-9955; E-mail: noventurenoglory@gmail.com strength and physical function are now also included in the definition of sarcopenia. Developing sarcopenia treatment is very important, with nutrition and exercise therapies and several potential targets for pharmacological interventions having been identified as possible treatment options [5-7].

Sarcopenic obesity is defined as having both sarcopenia and obesity. Heber et al. [8] proposed a clinical definition of sarcopenic obesity as obese patients with the lowest tertile of fat-free mass estimated by bioelectrical impedance analysis. Obesity is defined as people with a body mass index (BMI) of $30 \mathrm{~kg} / \mathrm{m}^{2}$ or greater, while those with a BMI between 25 and $29.9 \mathrm{~kg} / \mathrm{m}^{2}$ were classified as overweight. The causes of sarcopenic obesity are multi-factorial and can include factors such as lifestyle (diet, physical activity, and smoking), endocrine (corticosteroids, growth factors, insulin, and catecholamines), vascular (endothelial function and coagulation), and immunology (inflammation and reactive oxygen species) [9].

The prevalence of sarcopenic obesity in elderly individuals is estimated to range between $2.75 \%$ to 19.8\% [9]. The diagnostic criteria for sarcopenic obesity have varied considerably between studies. For example, sarcopenic obesity was classified as 
appendicular skeletal muscle with a value lower than 2 standard deviations from that measured in the healthy population, and a fat mass greater than the $60^{\text {th }}$ percentile of an age-matched population [10, 11]. Another study classified sarcopenic obesity as cases with a percentage body fat in the upper two quintiles and a relative muscle mass in the lower two quintiles [12]. Muscle mass and fat mass are assessed by several methods including BMI, mid-upper arm circumference, bioelectrical impedance analysis, dual energy X-ray absorptiometry, and computer tomography [2]. However, there is no standardized definition and diagnostic criteria for sarcopenic obesity.

Sarcopenic obesity is associated with adverse health effects such as physical disability, cardiovascular disease risk, and death [10, 11, 13, 14]. The relative risk (RR) for incident disability in obese sarcopenic subjects was reported to be 2.63 (95\% confidence interval (Cl), 1.19 to 5.85 ) after adjustment for age, sex, physical activity level, length of follow-up, and prevalent morbidity in the elderly [10]. Significantly higher odds ratios (ORs) for difficulty climbing stairs (OR, 2.45; 95\% Cl 0.99 to 6.04 ), going down stairs (OR, 3.41; $95 \% \mathrm{Cl}, 1.35$ to 8.57 ), or rising from a chair or bed (OR, 2.89; $95 \% \mathrm{Cl}, 1.01$ to 8.30$)$ were observed more frequently in women with sarcopenic obesity than in women with sarcopenia alone [11]. Cardiovascular disease risk was also reported to be increased by $23 \%$ $(95 \% \mathrm{Cl}, 0.99$ to 1.54$)$ in a sarcopenic-obese group in community-dwelling elderly subjects [12]. In addition, sarcopenic obesity was found to be an independent predictor of survival (hazard ratio $(\mathrm{HR}), 4.2 ; 95 \% \mathrm{Cl}$, 2.4 to 7.2) in patients with solid tumors of the respiratory and gastrointestinal tracts [13]. In contrast, other studies found no association between sarcopenic obesity and functional limitations [12, 15]. Despite these inconsistent findings between studies, sarcopenic obesity is regarded as an important current and future public health issue.

Numerous interventional studies for sarcopenia and obesity treatment have been performed. However, a literature search we conducted showed there are no intervention studies for sarcopenic obesity in humans. Therefore, it is necessary to make inferences from separate intervention studies on sarcopenia and obesity. In this review, we first review nutrition, exercise and pharmaceutical therapies used to treat sarcopenia and obesity in humans, and then summarize a comprehensive approach for inhibiting sarcopenic obesity.

\section{NUTRITION THERAPIES}

\subsection{Nutrition Therapies for Sarcopenia}

Protein and amino acid supplementation can counteract sarcopenia, as low protein intake is known to be associated with declining muscle mass in older adults [16]. A Cochrane Database of Systematic Review found that protein and energy supplementation produced a small but consistent weight gain of $2.2 \%$ in older people $(95 \% \mathrm{Cl}, 1.8$ to 2.5$)$, while mortality may be reduced in older people who are undernourished (RR, 0.79; 95\% Cl, 0.64 to 0.97) [11]. However, that review found no evidence of a reduction in the length of hospital stay with supplementation $(-0.8$ days; $95 \% \mathrm{Cl}$, -2.8 to 1.3) [17]. A recent systematic review on the effectiveness of nutritional supplementation on muscle mass in the treatment of sarcopenia in old age also confirmed an improvement in muscle mass and muscle strength [18]. Many essential acids including large amounts of leucine are needed to effectively counteract sarcopenia [6].

Consuming sufficient energy is important, as loss of muscle mass can be a result of calorie restriction or starvation. Biolo et al. [19] investigated the effects of the interaction of inactivity and calorie restriction on whole-body composition and protein kinetic regulation in nine healthy volunteers. Lean body mass was measured using dual-energy X-ray absorptionometry before and at the end of 14-day periods of bed rest and controlled ambulation in subjects receiving either a hypocaloric (approximately $80 \%$ of total energy expenditure) or normal diet. During the eucaloric period, lean body mass decreased $-0.1 \pm 0.1 \mathrm{~kg}$ during ambulatory conditions and $-0.3 \pm 0.2 \mathrm{~kg}$ with bed rest. During the hypocaloric periods, lean body mass decreased $-0.3 \pm 0.3 \mathrm{~kg}$ during ambulatory conditions and $-1.1 \pm 0.1 \mathrm{~kg}$ with bed rest $(p<0.01$ for activity effect; $p=0.04$ for diet effect; $p=0.03$ for interaction). These results indicate that physical inactivity under conditions of negative energy balance may lead to a rapid loss of lean body mass, and that such a catabolic effect can be prevented, at least in the short term, by a moderate level of physical activity. Evidence from other studies also suggests that maintaining protein intake during a period of disuse attenuates disuse atrophy [20], with $91 \%$ of patients with the disuse syndrome being classified as malnourished [21]. Maintaining energy and protein intake and physical activity is therefore important for preventing sarcopenia. 
Because both resistance training and protein supplementation are effective treatments for sarcopenia, resistance training combined with supplements containing amino acids would be expected to be the most effective option for preventing and treating age-related muscle wasting and weakness [5-7]. Kim et al. [22] found that the combination of exercise and amino acid supplementation were effective for enhancing muscle strength, muscle mass, and walking speed in sarcopenic women. In a metaanalysis of protein supplementation during prolonged resistance-type exercise training, protein supplementation showed a positive effect on fat-free mass and one-repetition maximum leg press strength compared with placebo in both younger and older subjects [23]. Therefore, treatment of sarcopenia should include resistance training and protein and amino acid supplementation.

\subsection{Nutrition Therapies for Obesity}

Low-calorie diets can counteract obesity, as reducing caloric intake below expenditure results in weight loss. For example, a balanced diet providing an energy deficit of 500 to $750 \mathrm{kcal}$ per day from daily energy requirements with approximately $1 \mathrm{~g}$ of highquality protein per kilogram of body weight per day was prescribed in a 1-year, randomized, controlled trial on combined weight loss and exercise [24]. An initial weight loss goal of more than $5 \%$ was realistic and appeared to be associated with improvements in cardiovascular risk factors mainly in people with several concomitant factors [25].

There are many types of diets that produce weight loss. Balanced low-calorie diets are a standard strategy for losing body weight. Meta-analyses also showed low-carbohydrate diets were associated with significant decreases in body weight $(-7.04 \mathrm{~kg} ; 95 \% \mathrm{Cl},-7.20$ to 6.88) [26], whereas lower total fat intake was associated with a lower relative body weight $(-1.6 \mathrm{~kg}$; $95 \% \mathrm{Cl},-2.0$ to -1.2 ) [27]. A meta-analysis comparing low-carbohydrate and low-fat diets demonstrated that individuals assigned to low-carbohydrate diets lost more weight than individuals randomized to low-fat diets (weighted mean difference (WMD), $-3.3 \mathrm{~kg}$; $95 \%$ $\mathrm{Cl},-5.3$ to -1.4 ) after 6 months [28]. However, this difference was no longer obvious after 12 months (WMD, $-1.0 \mathrm{~kg} ; 95 \% \mathrm{Cl},-3.5$ to 1.5 ) [28]. Another metaanalysis showed that reduction in body weight was not significantly different between low-carbohydrate and low-fat diets [29].

Meta-analysis also showed high-protein diets produced more weight loss than low-protein diets (standardized mean difference (SMD) $-0.36 ; 95 \% \mathrm{Cl}$, 0.56 to -0.17 ) [30]. Another meta-analysis showed that energy-restricted, isocaloric, high-protein and low-fat diets were better for reducing body weight $(0.79 \mathrm{~kg}$; $95 \% \mathrm{Cl},-1.50$ to -0.08$)$ and fat mass $(-0.87 \mathrm{~kg} ; 95 \% \mathrm{Cl}$, -1.26 to $-0.48 \mathrm{~kg}$ ), compared with a standard-protein, low-fat diet [31]. The Mediterranean diet was also reported to have a significant effect on weight (mean difference (MD) between $-1.75 \mathrm{~kg} ; 95 \% \mathrm{Cl},-2.86$ to 0.64) [32]. In a Cochrane Database of Systematic Review, diets with a low glycemic index or low glycemic load were shown to result in a greater decrease in body weight (WMD $-1.1 \mathrm{~kg} ; 95 \% \mathrm{Cl}-2.0$ to -0.2 ) [33]. Verylow-calorie diets that provided less than $800 \mathrm{kcal} /$ day have been used to induce rapid weight loss. Very-lowcalorie diets induced significantly greater short-term weight losses $(16.1 \pm 1.6 \%$ vs. $9.7 \pm 2.4 \%$ of initial weight, respectively; $p=0.0001$ ) compared with conventional low-calorie diets that provided between 800 and $1800 \mathrm{kcal} /$ day [34]. However, there were no significant long-term weight losses with the two diets $(6.3 \pm 3.2 \%$ vs. $5.0 \pm 4.0 \%$, respectively; $p>0.2)$ [34].

Although intervention with a low-calorie diet only was effective for reducing body weight, meta-analysis showed a pooled weight loss of $1.14 \mathrm{~kg}(95 \% \mathrm{Cl}, 0.21$ to 2.07) was greater in the diet-plus-exercise group than the diet-only group [35]. In a 1-year, randomized, controlled trial, combination of a low-calorie diet and exercise were shown to maintain more lean body mass than either intervention alone [24]. On the basis of these results, a combination of a low-calorie diet and exercise would be recommended for obese elderly subjects.

\section{EXERCISE THERAPIES}

\subsection{Exercise Therapies for Sarcopenia}

Resistance training has been shown to be the most promising intervention for decreasing the effects of sarcopenia, as it induces skeletal muscle hypertrophy, and enhances muscle strength. A systematic review of the effects of exercise intervention for increasing muscle mass in elderly subjects identified 5 of 6 articles that concluded high-intensity resistance training resulted in significant increases in soft lean tissue and muscle mass [36]. On the other hand, the remaining three articles indicated that moderate-intensity resistance training did not affect soft lean tissue or muscle mass [36]. High-intensity resistance training of sufficient duration, frequency, repetitions, and sets is therefore effective for counteracting the loss of muscle mass associated with advancing age. 
A meta-analysis of resistance exercise for muscular strength in older adults revealed that higher intensity training was associated with greater improvement in strength [37]. The increases in strength ranged from 9.8 to $31.6 \mathrm{~kg}$, while the percent changes were $29 \pm 2$, $24 \pm 2,33 \pm 3$, and $25 \pm 2$ for leg presses, chest presses, knee extensions, and lateral pulls, respectively [37]. A Cochrane Database of Systematic Review reported progressive resistance strength training was also an effective intervention for improving physical functioning in older people as it increased muscle strength (SMD, $0.84 ; 95 \% \mathrm{CI}, 0.67$ to 1.00 ) and gait speed (MD, $0.08 \mathrm{~m} / \mathrm{s} ; 95 \% \mathrm{Cl}, 0.04$ to 0.12$)$ in older adults [38]. Careful attention should be paid when determining the amount and frequency of resistance training in the elderly, as excess intensive strength training in these people may impair effective gains in muscle strength and mass.

During disuse, skeletal muscle loss occurs at a rate of approximately $0.5 \%$ of total muscle mass per day [20]. The substantial loss of skeletal muscle mass during disuse is accompanied by a decline in strength ranging between $0.3 \%$ and $4.2 \%$ per day [20]. Physical activity and aerobic exercise are therefore important not only for increasing muscle mass, but also for maintaining muscle mass and preventing sarcopenia. Daily ambulatory activity with moderate intensity estimated by accelerometer has been shown to correlate positively with lower body muscle size and function in older adults [39]. Although there is conflicting data on the effects of short-term ambulation training, it is possible that relatively long periods of walking, jogging, or intermittent running for over half a year can increase leg muscle size in elderly adults [39].

\subsection{Exercise Therapies for Obesity}

Exercise and physical activity has beneficial effects, not only in causing a loss of weight but also reducing cardiovascular risk [40]. A Cochrane Database of Systematic Review reported that exercise combined with diet resulted in a greater weight reduction than diet alone (WMD $-1.1 \mathrm{~kg} ; 95 \% \mathrm{Cl},-1.5$ to -0.6 ), while raising exercise intensity increased the magnitude of weight loss (WMD $-1.5 \mathrm{~kg} ; 95 \% \mathrm{Cl},-2.3$ to -0.7 ) [41]. A metaanalysis of isolated aerobic exercise and weight loss showed that 6-month exercise programs were associated with a modest reduction in weight (WMD $1.6 \mathrm{~kg} ; 95 \% \mathrm{Cl},-1.64$ to -1.56 ), while a 12-month program was also associated with a modest reduction in weight (WMD $-1.7 \mathrm{~kg} ; 95 \% \mathrm{Cl},-2.29$ to -1.11 ) [42]. Another meta-analysis showed that pedometer-based walking interventions were associated with weight loss $(-1.27 \mathrm{~kg} ; 95 \% \mathrm{Cl},-1.85$ to -0.70$)$, with participants losing an average $0.05 \mathrm{~kg}$ per week during the intervention [43]. These results indicate that aerobic exercise alone can induce weight loss. However, a lowcalorie diet should be combined with exercise as the effect of aerobic exercise on weight reduction is minimal.

Resistance training is another exercise therapy for obesity. A meta-analysis showed resistance training reduced fat mass by $2.33 \mathrm{~kg}(95 \% \mathrm{Cl},-4.71$ to 0.04$)$ in patients with abnormal glucose metabolism [44]. A systematic review on the effect of exclusive resistance training on body composition and cardiovascular risk factors in overweight or obese children, showed that 4 of 6 studies reported significant changes in body composition, with an increase in fat-free mass and BMI associated with a decrease in fat mass [45].

A meta-analysis of aerobic versus resistance exercise training on reduction of visceral fat showed that there was a significant pooled effect size for the comparison between aerobic exercise and controls ($0.33 ; 95 \% \mathrm{Cl},-0.52$ to -0.14$)$, but not for the comparison between progressive resistance training and controls $(0.09 ; 95 \% \mathrm{Cl},-0.17$ to 0.36$)$ [46]. This result suggests that aerobic exercise is a central point for exercise programs aimed at reducing visceral fat. However, recent randomized, controlled trials on the effect of 12 weeks of aerobic, resistance or combination exercise training on cardiovascular risk factors in overweight and obese subjects demonstrated there were significant improvements in body weight ($1.6 \%, p=0.044)$ in the combination exercise group compared with the control and resistance groups [47]. Significant improvements in body fat percentage ($2.6 \%, p=0.008)$ and abdominal fat percentage $(-2.8 \%$, $\mathrm{p}=0.034)$ were also observed in the combination exercise group compared with controls [47]. A combination of aerobic exercise and resistance training is therefore recommended for overweight and obese adults.

\section{PHARMACEUTICAL THERAPIES}

\subsection{Pharmaceutical Therapies for Sarcopenia}

\subsubsection{Testosterone}

Although the mechanisms by which testosterone increases skeletal muscle are poorly understood, it has been shown to positively regulate insulin-like growth factor-1 and myostatin [5]. A meta-analysis indicated 
that testosterone supplementation increased fat-free mass and muscle strength in men aged older than 45 years with low or low-normal testosterone levels [48]. Testosterone replacement was associated with a significantly greater increase in lean body mass $(2.7$ $\mathrm{kg} ; 95 \% \mathrm{Cl}, 1.6$ to 3.7$)$, grip strength $(3.3 \mathrm{~kg} ; 95 \% \mathrm{Cl}$, 0.7 to 5.8$)$, and a greater reduction in fat mass $(-2.0 \mathrm{~kg}$; $95 \% \mathrm{Cl},-3.1$ to -0.8$)$ compared with placebo [48]. Another meta-analysis of testosterone or dihydrotestosterone replacement therapy in men with a mean age of 65 years or greater revealed that the mean $g$-index adjusted for sample size was $0.53(95 \%$ $\mathrm{Cl}, 0.21$ to 0.86 ) [49]. A mean g-index of 0.53 indicated that androgen treatment produced an approximately $19.3 \%$ increase in muscle strength [49].

Although testosterone treatment resulted in significant increases in fat-free mass and muscle strength, a meta-analysis of adverse effects of testosterone therapy in adult men showed it was also associated with a significant increase in hemoglobin (WMD, $0.80 \mathrm{~g} / \mathrm{dl} ; 95 \% \mathrm{Cl}, 0.45$ to 1.14 ) and hematocrit (WMD, 3.18\%; 95\% Cl, 1.35 to 5.01), and a decrease in high-density lipoprotein cholesterol (WMD, -0.49 $\mathrm{mg} / \mathrm{dl} ; 95 \% \mathrm{Cl},-0.85$ to -0.13 ) [50]. No significant effects on mortality, prostate disease, or cardiovascular outcomes were observed in that study [50]. On the other hand, a testosterone gel was shown to be associated with an increased risk of cardiovascular adverse events (total risk OR, 10.6; $95 \% \mathrm{Cl}, 1.3$ to 84.5) in older men with limited mobility and a high prevalence of chronic disease [51]. Testosterone increases fat-free mass and muscle strength, and if no contraindications for its use are apparent it could be used as a first-line pharmaceutical therapy in sarcopenic elderly men for several months whilst monitoring side effects.

\subsubsection{Growth Hormone}

Growth hormone $(\mathrm{GH})$ is a single-chain peptide of 191 amino acids, produced and secreted mainly by the somatotrophs of the anterior pituitary gland. GH coordinates the postnatal growth of multiple target tissues, including skeletal muscle. A systematic review of randomized, controlled trials of $\mathrm{GH}$ therapy in healthy, elderly subjects showed that those treated with $\mathrm{GH}$ therapy had a decreased overall fat mass $(-2.1 \mathrm{~kg}$; $95 \% \mathrm{Cl},-2.8$ to -1.35$)$ and increased overall lean body mass $(2.1 \mathrm{~kg} ; 95 \% \mathrm{Cl}, 1.3$ to 2.9$)$, compared with those not receiving treatment [52]. However, subjects treated with $\mathrm{GH}$ were shown to be significantly more likely to experience soft tissue edema, arthralgias, carpal tunnel syndrome, and gynecomastia, and were somewhat more likely to develop diabetes mellitus and impaired fasting glucose. Therefore, $\mathrm{GH}$ therapy cannot be recommended as sarcopenia treatment in healthy, elderly subjects due to its adverse effects [52].

Subsequent to this systematic review, another study in healthy, elderly adults showed administration of the oral GH secretagogue, capromorelin, improved body composition and physical function (lean body mass increased with capromorelin $1.4 \mathrm{~kg}$ vs. placebo $0.3 \mathrm{~kg}$, $p=0.001$ ) [53]. Adverse events included fatigue, insomnia, and small increases in fasting glucose, glycosylated hemoglobin, and indices of insulin resistance [53]. Several randomized, controlled trials on growth hormone and/or testosterone in healthy, elderly subjects also revealed that body composition and muscle performance were improved and enhanced by $\mathrm{GH}$ supplementation [54-57]. For example, lean body mass increased by $2.0 \pm 0.5 \mathrm{~kg}$ in the $\mathrm{GH}$ group $(p=0.004)$ and by $1.8 \pm 0.5 \mathrm{~kg}$ in the $\mathrm{GH}$ and testosterone group $(p=0.007)$ compared with placebo [54]. However, GH therapy is still not recommended as a treatment for sarcopenia due to its adverse effects.

\subsubsection{Ghrelin}

Ghrelin is a 28-amino-acid peptide produced mainly by cells in the stomach, and is a natural ligand for the GH-secretagogue receptor [58]. Ghrelin plays a critical role in a variety of physiological processes, by stimulating $\mathrm{GH}$ secretion and regulating energy homeostasis by stimulating food intake and promoting adiposity via a $\mathrm{GH}$-independent mechanism. Because of their combined anabolic effects on skeletal muscle and appetite, ghrelin and low-molecular-weight agonists of the ghrelin receptor are considered attractive candidates for treating sarcopenia.

Oral administration of the ghrelin mimetic MK-677 at a dose of $25 \mathrm{mg}$ once daily for 1 year in healthy elderly adults older than 60 years was shown to cause significant increases in fat-free mass (placebo $-0.5 \mathrm{~kg}$; $95 \% \mathrm{Cl},-1.1$ to 0.2 , vs. ghrelin mimetic $1.1 \mathrm{~kg} ; 95 \% \mathrm{Cl}$, 0.7 to $1.5, \mathrm{p}<0.001$ ) [59]. However, that study did not show a significant increase in strength or function in the ghrelin-mimetic treatment group, compared with the placebo group. Patients with osteoarthritis undergoing elective total hip replacement who received intravenous injections of $2 \mathrm{mg} / \mathrm{kg}$ of ghrelin twice-daily for 3 weeks beginning 1 week before surgery, had significant increases in lean body mass $(p=0.012)$ and decreases in fat mass $(p=0.017)$ [60]. In contrast, muscle strength and walking ability did not differ significantly [60]. Although ghrelin appears to increase 
lean body mass in the elderly, increased fat-free mass may not result in changes in muscle strength or physical function. Long-term, large-scale clinical trials are therefore required to recommend ghrelin as a treatment for sarcopenia.

\subsubsection{Vitamin $D$}

Vitamin $D$ deficiency is one cause of proximal myopathy and sarcopenia which improves with vitamin D supplementation [61, 62]. Vitamin D appears to down-regulate myostatin expression and up-regulate follistatin expression, an inhibitor of myostatin. As a low vitamin $D$ level has been shown to be associated with an increased risk of mobility limitation and disability in community-dwelling subjects [63], vitamin D supplementation appears a reasonable treatment option in sarcopenia, especially in elderly subjects with vitamin $D$ deficiency. An association between low vitamin $D$ and low muscle mass has been reported in several studies [64-67]. On the other hand, Marantes et al. [68] found the association between low vitamin D and low muscle mass occurred only in subjects younger than 65 years.

A systematic review that examined mainly community-dwelling, older women showed the association between vitamin $\mathrm{D}$ supplementation and physical performance remained controversial [69]. Four of the 5 studies and 2 of the 3 studies which tested the effect of vitamin D supplementation on balance and gait, respectively, showed no significant effect [69]. Four studies showed a significant effect on muscle strength, although this effect was not observed in three other studies [69]. In a recent systematic review and meta-analysis of 17 randomized, controlled trials, vitamin D supplementation was reported to have no significant effect on grip strength (SMD, $-0.02 ; 95 \% \mathrm{Cl}$, -0.15 to 0.11 ) or proximal lower limb strength (SMD, $0.1 ; 95 \% \mathrm{Cl},-0.01$ to 0.22$)$ in adults with a baseline $25(\mathrm{OH}) \mathrm{D}>25 \mathrm{nmol} / \mathrm{L}$ [70]. However, pooled data from two studies on vitamin D-deficient participants $(25(\mathrm{OH}) \mathrm{D}<25 \mathrm{nmol} / \mathrm{L})$ demonstrated a large effect of vitamin $D$ supplementation on hip muscle strength (SMD, 3.52; 95\% Cl, 2.18 to 4.85) [70]. Vitamin D supplementation is therefore recommended for increasing muscle strength only in elderly subjects with vitamin $\mathrm{D}$ deficiency.

\subsection{Pharmaceutical Therapies for Obesity}

\subsubsection{Orlistat}

Orlistat alters fat digestion by inhibiting pancreatic lipase and induces weight loss by increasing fecal fat excretion, due to the fat not being completely hydrolyzed. A Cochrane Database of Systematic Review showed obese and overweight patients treated with orlistat lost $2.7 \mathrm{~kg}$ of weight $(95 \% \mathrm{Cl}, 2.3$ to 3.1$)$ compared with placebo [71]. The number of patients achieving $10 \%$ or greater weight loss was $12 \%$ higher (95\% Cl, 8 to 16) with orlistat therapy [71]. An updated meta-analysis of long-term pharmacotherapy for obesity and overweight revealed that orlistat reduced weight by $2.9 \mathrm{~kg}(95 \% \mathrm{Cl}, 2.5$ to 3.2$)$ compared with placebo [72]. A recent meta-analysis on the effects of anti-obesity drugs on cardiovascular risk factors showed that orlistat treatment was associated with a reduction of $2.39 \mathrm{~kg}$ in weight $(95 \% \mathrm{Cl},-3.34$ to -1.45$)$, a reduction of $0.27 \mathrm{mmol} / \mathrm{L}$ in total cholesterol $(95 \% \mathrm{Cl}$, -0.36 to -0.17$)$, a reduction of $0.21 \mathrm{mmol} / \mathrm{L}$ in lowdensity lipoprotein $(95 \% \mathrm{Cl},-0.30$ to -0.12$)$, a reduction of $0.12 \mathrm{mmol} / \mathrm{L}$ in fasting glucose $(95 \% \mathrm{Cl},-0.20$ to 0.04 ), a reduction of $1.85 \mathrm{mmHg}$ in systolic blood pressure $(95 \% \mathrm{Cl},-3.30$ to -0.40$)$, and a reduction of $1.49 \mathrm{mmHg}$ in diastolic blood pressure $(95 \% \mathrm{Cl},-2.39$ to -0.58) [73]. Orlistat is suggested as first-line pharmaceutical therapy for obesity as there is no evidence it is associated with an increased risk of cardiovascular events.

\subsubsection{Lorcaserin}

Lorcaserin is a selective agonist of the serotonin $2 \mathrm{c}$ receptor, and selectively activates central receptors and decreases food intake through the proopiomelanocortin system of neurons. In 2012, the United States Food and Drug Administration approved lorcaserin as an addition to a reduced-calorie diet and exercise regimen for obese or overweight (BMI $\geq 27$ $\mathrm{kg} / \mathrm{m}^{2}$ ) patients with at least one medical comorbidity, such as type 2 diabetes, hypertension, high cholesterol, or sleep apnea. A meta-analysis of randomized, controlled trials of 1 year duration reported weight loss of $3.23 \mathrm{~kg}(95 \% \mathrm{Cl}, 2.70$ to 3.75$)$ and a reduction in $\mathrm{BMI}$ of $1.16 \mathrm{~kg} / \mathrm{m}^{2}(95 \% \mathrm{Cl}, 0.98$ to 1.34$)$ compared with placebo [74]. The use of lorcaserin for 8 and 12 weeks reduced weight by $1.60 \mathrm{~kg}(95 \% \mathrm{Cl}, 0.34$ to 2.86$)$ and $2.9 \mathrm{~kg}(95 \% \mathrm{Cl}, 2.2$ to 3.5$)$, respectively [74]. Headache, nausea, and dizziness were found to be significantly higher in patients receiving lorcaserin than those receiving placebo [74]. Data on long-term weight loss and safety with lorcaserin treatment are still required.

\subsubsection{Phentermine-Topiramate}

Phentermine is a noradrenergic sympathomimetic drug that stimulates the release of norepinephrine or 
inhibits its reuptake into nerve terminals. Topiramate is an antiepileptic drug used to treat certain types of seizures in people who have epilepsy. In 2012, the United States Food and Drug Administration approved the combination of phentermine and topiramate for weight loss in obese or overweight (BMI $\geq 27 \mathrm{~kg} / \mathrm{m}^{2}$ ) patients with at least one medical comorbidity.

In the CONQUER randomized, controlled trial, changes in bodyweight after 56 weeks were $-1.4 \mathrm{~kg}$ (least-squares mean $-1.2 \% ; 95 \% \mathrm{Cl},-1.8$ to -0.7 ), -8.1 $\mathrm{kg}(-7.8 \% ; 95 \% \mathrm{Cl},-8.5$ to $-7.1 ; \mathrm{p}<0.0001)$, and -10.2 $\mathrm{kg}(-9.8 \% ; 95 \% \mathrm{Cl},-10.4$ to $-9.3 ; \mathrm{p}<0.0001)$ in patients assigned to placebo, phentermine $7.5 \mathrm{mg}$ plus topiramate $46.0 \mathrm{mg}$, or phentermine $15.0 \mathrm{mg}$ plus topiramate $92.0 \mathrm{mg}$, respectively [75]. In the EQUIP randomized, controlled trial, patients in the placebo, phentermine $3.75 \mathrm{mg}$ plus topiramate $23 \mathrm{mg}$, and phentermine $15 \mathrm{mg}$ plus topiramate $92 \mathrm{mg}$ groups lost $1.6 \%, 5.1 \%$, and $10.9 \%$ of baseline body weight after 56 weeks, respectively $(p<0.0001)$ [76]. The SEQUEL randomized, controlled trial showed weight loss was maintained for over 2 years with $9.3 \%$ and $10.5 \%$ weight loss from baseline for phentermine $7.5 \mathrm{mg}$ plus topiramate $46 \mathrm{mg}$ and phentermine $15 \mathrm{mg}$ plus topiramate $92 \mathrm{mg}$, respectively $(p<0.0001)$ [77]. Adverse reactions occurred in $5 \%$ or more of the study subjects and included parasthesia, dizziness, dysgeusia, insomnia, constipation, and a dry mouth [78]. Long-term weight loss and safety data of phentermine-topiramate treatment is necessary before its use as a first-line treatment can be recommended.

\subsubsection{Vitamin $D$}

An association between low vitamin $D$ and obesity has been reported [79-80]. A meta-analysis indicated that there was a significant inverse weak correlation between serum 25(OH)D levels and BMI in adult population (Fisher's $\mathrm{Z}=-0.15 ; 95 \% \mathrm{Cl},-0.19$ to -0.11 ), except for women living in developing countries [79]. Another meta-analysis revealed that each $1 \mathrm{~kg} / \mathrm{m}^{2}$ higher BMI was associated with $1.15 \%$ lower $25(\mathrm{OH}) \mathrm{D}$ [80]. Low vitamin $D$ level has been also shown to be associated with sarcopenic obesity in adult population [67, 81-83]. On the other hand, Kim et al. [66] found the association between low vitamin $D$ and sarcopenia, regardless of obesity in the older population.

The effect of vitamin D supplementation on obesity remains controversial. A randomized, double blind clinical trial with 20,000 IU cholecalciferol twice a week, or 20,000 IU once a week plus placebo, or placebo twice a week for 12 months reported that there was no significant change in weight, waist-to-hip ratio or percentage body fat in any of the groups [84]. Another randomized, controlled trial showed that weight loss was not affected significantly by vitamin D supplementation ( $83 \mu \mathrm{g}$ per day) or placebo $(-5.7 \pm 5.8$ $\mathrm{kg}$ vs. $-6.4 \pm 5.6 \mathrm{~kg} ; \mathrm{p}=0.248$ ) [85]. Supplementation with vitamin $\mathrm{D}(25 \mu \mathrm{g}$ per day as cholecalciferol) for 12 weeks caused a statistically significant decrease in body fat mass in the vitamin $D$ group compared to the placebo group $(-2.7 \pm 2.1 \mathrm{~kg}$ vs. $-0.47 \pm 2.1 \mathrm{~kg}$; $\mathrm{p}<0.001$ ) [86]. However, body weight and waist circumference did not change significantly in both groups. Rosenblum et al. [87] found that calcium and vitamin D supplemented orange juice (1050 mg calcium and 300 IU vitamin D per day) was not effective for weight change in overweight and obese adults $(-2.1 \pm 2.7 \mathrm{~kg}$ vs. $-2.8 \pm 3.7 \mathrm{~kg}, \mathrm{p}=0.3748)$. In contrast, the reduction of visceral adipose tissue was significantly greater in the calcium and vitamin $D$ group than in the control group. Further clinical trials are therefore required to recommend vitamin $\mathrm{D}$ as a treatment for obesity.

\section{COMPREHENSIVE APPROACH}

Sarcopenia treatment should include resistance training and protein and amino acid supplementation. Physical activity and aerobic exercise are important for maintaining muscle mass and preventing sarcopenia. Obesity treatment should include low-calorie, highprotein diets, aerobic exercise, and resistance training. A combination of nutrition therapies (low-calorie, highprotein diets, protein and amino acid supplementation) and exercise therapies (resistance training and aerobic exercise) would therefore be expected to be the most effective option for preventing and treating sarcopenic obesity.

A systematic review of the separate and combined effects of energy restriction and exercise on fat-free mass in middle-aged and older adults revealed that $81 \%$ of the energy restriction groups and $39 \%$ of the energy restriction plus exercise groups lost $\geq 15 \%$ of their body weight as fat-free mass [88]. The exercise groups had modest changes in body weight and fatfree mass [88]. Another review of 18 randomized, controlled trials of exercise with or without diet components indicated that $3-18$ month programs that included aerobic and strengthening exercise (2-3 days per week) with calorie restriction (typically $750 \mathrm{kcal}$ deficit/day), induced the greatest change in functional performance measures compared with exercise or diet 


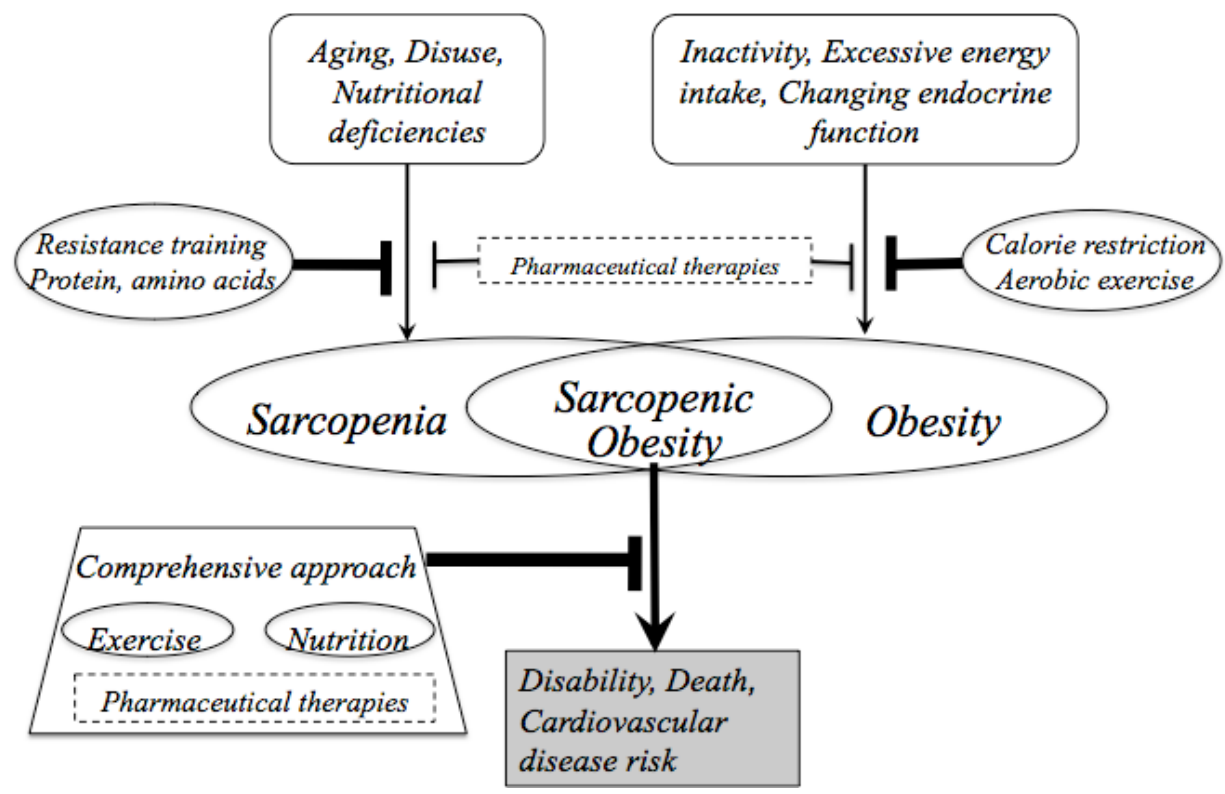

Figure 1: Comprehensive approach to sarcopenic obesity including nutrition, exercise, and pharmaceutical therapies.

alone [89]. Sakuma et al. [90] recommended multiple exercises including flexibility training, aerobic exercise, and resistance training, combined with nutrition therapy including caloric restriction (range of 200-750 kcal) and higher intake of protein (up to $1.5 \mathrm{~g} / \mathrm{kg}$ ) of high biological quality to attenuate the symptoms of sarcopenic obesity. However, there have been no intervention studies for sarcopenic obesity, with only observational studies having been reported for the condition. This is due partly to the fact that there is no standardized definition or diagnostic criteria for sarcopenic obesity. Therefore, future research for counteracting sarcopenic obesity should consider determining a standardized definition and diagnostic criteria for the condition and also undertake a multimodal intervention study for sarcopenic obesity.

In case of severe sarcopenic obesity or failure to achieve muscle gain and weight loss through nutrition and exercise therapies, pharmaceutical therapies can be added to treat the condition. In a systematic review of adding drug therapy, exercise, behavior therapy, or combinations of these interventions for obesity indicated that adding orlistat, exercise, or behavior modification to dietary advice improved long-term weight loss [91]. Weight loss program using a very-lowenergy diet and orlistat induced both fat loss and fatfree mass loss (fat-free mass to fat mass loss ratio: 1 to 5.9) [92]. In contrast, testosterone replacement was associated with increasing lean body mass and reducing fat mass [48]. In the comprehensive approach for sarcopenic obesity, testosterone or orlistat can be suggested as first-line pharmaceutical therapies, depending on the severity of sarcopenia and obesity. Vitamin D supplementation is recommended in elderly subjects with vitamin $D$ deficiency. However, careful attention should be paid to the adverse effects of testosterone, orlistat, and vitamin D supplementation.

\section{CONCLUSION}

Sarcopenic obesity is an important current and future public health issue. The impact of sarcopenic obesity on physical disability, cardiovascular disease risk, and death is becoming a primary concern amongst nutritionists, geriatricians, and public health officers. Although there are no intervention studies for sarcopenic obesity, nutrition therapies should include caloric restriction (range of 200-750 kcal), high protein diets (up to $1.5 \mathrm{~g} / \mathrm{kg}$ ), and protein and amino acid supplementation. Exercise therapies for sarcopenic obesity should include both aerobic exercise and resistance training. A combination of nutrition and exercise therapies would be expected to be the most effective option for preventing and treating sarcopenic obesity. In cases of severe sarcopenic obesity or failure to achieve muscle gain and weight loss through nutrition and exercise therapies, pharmaceutical therapies such as testosterone, orlistat, and vitamin D supplementation can be added to the treatment regimen. As shown in Figure 1, the comprehensive approach to sarcopenic obesity includes nutrition, exercise, and pharmaceutical therapies.

\section{CONFLICT OF INTEREST}

All authors declare no conflicts of interest. 


\section{ACKNOWLEDGEMENTS}

This study was supported by a Grant-in-Aid for the Comprehensive Research on Aging and Health from the Ministry of Health, Labor, and Welfare of Japan.

\section{REFERENCES}

[1] Rosenberg IH. Summary comments: epidemiological and methodological problems in determining nutritional status of older persons. Am J Clin Nutr 1989; 50: 1231-3. Reference: Available from: URL http://ajcn.nutrition.org/content/50/ 5/1231.full.pdf

[2] Rosenberg IH. Sarcopenia: Origins and clinical relevance. J Nutr 1997; 127: 990S-1S. Reference: Available from: URL http://jn.nutrition.org/content/127/5/990S.long

[3] Cruz-Jentoft AJ, Baeyens JP, Bauer JM, Boirie Y, Cederholm $\mathrm{T}$, Landi $\mathrm{F}$, et al. Sarcopenia: European consensus on definition and diagnosis: Report of the European Working Group on Sarcopenia in Older People. Age Ageing 2010; 39: 412-23.

http://dx.doi.org/10.1093/ageing/afq034

[4] Fielding RA, Vellas B, Evans WJ, Bhasin S, Morley JE, Newman $A B$, et al. Sarcopenia: an undiagnosed condition in older adults. Current consensus definition: prevalence, etiology, and consequences. International working group on sarcopenia. J Am Med Dir Assoc 2011; 12: 249-56. Reference: Available from: URL http://www.ncbi.nlm.nih.gov/ pmc/articles/PMC3377163/

[5] Sakuma K, Yamaguchi A. Molecular mechanisms in aging and current strategies to counteract sarcopenia. Curr Aging Sci 2010; 3: 90-101 http://dx.doi.org/10.2174/1874609811003020090

[6] Sakuma K, Yamaguchi A. Sarcopenia: molecular mechanisms and current therapeutic strategy. In Cell Aging, Nova Science Publishers, Huntington, NY, USA, 2011, pp 93-152.

[7] Sakuma K, Yamaguchi A. Novel intriguing strategies attenuating to sarcopenia. J Aging Res 2012; 251217. http://dx.doi.org/10.1155/2012/251217

[8] Heber D, Ingles S, Ashley JM, Maxwell MH, Lyons RF, Elashoff RM. Clinical detection of sarcopenic obesity by bioelectrical impedance analysis. Am J Clin Nutr 1996; 64(3 Suppl): 472S-7S. Reference: Available from: URL http://ajcn.nutrition.org/content/64/3/472S.long

[9] Prado CM, Wells JC, Smith SR, Stephan BC, Siervo M. Sarcopenic obesity: A critical appraisal of the current evidence. Clin Nutr 2012; 31: 583-601. http://dx.doi.org/10.1016/j.clnu.2012.06.010

[10] Baumgartner RN, Wayne SJ, Waters DL, Janssen I, Gallagher D, Morley JE. Sarcopenic obesity predicts instrumental activities of daily living disability in the elderly. Obes Res 2004; 12: 1995-2004.

http://dx.doi.org/10.1038/oby.2004.250

[11] Rolland Y, Lauwers-Cances V, Cristini C, Abellan van Kan G, Janssen I, Morley JE, et al. Difficulties with physical function associated with obesity, sarcopenia, and sarcopenic-obesity in community-dwelling elderly women: the EPIDOS (EPIDemiologie de I'OSteoporose) Study. Am J Clin Nutr 2009; 89: 1895-900.

http://dx.doi.org/10.3945/aicn.2008.26950

[12] Davison KK, Ford ES, Cogswell ME, Dietz WH. Percentage of body fat and body mass index are associated with mobility limitations in people aged 70 and older from NHANES III. J Am Geriatr Soc 2002; 50: 1802-9.

http://dx.doi.org/10.1046/.1532-5415.2002.50508.x
$[13]$

Stephen WC, Janssen I. Sarcopenic-obesity and cardiovascular disease risk in the elderly. J Nutr Health Aging 2009; 13: 460-6.

http://dx.doi.org/10.1007/s12603-009-0084-z

[14] Prado CM, Lieffers JR, McCargar LJ, Reiman T, Sawyer MB, Martin L, et al. Prevalence and clinical implications of sarcopenic obesity in patients with solid tumours of the respiratory and gastrointestinal tracts: a population-based study. Lancet Oncol 2008; 9: 629-35 http://dx.doi.org/10.1016/S1470-2045(08)70153-0

[15] Bouchard DR, Dionne IJ, Brochu M. Sarcopenic/obesity and physical capacity in older men and women: data from the Nutrition as a Determinant of Successful Aging (NuAge)-the Quebec longitudinal Study. Obesity (Silver Spring) 2009; 17: 2082-8.

http://dx.doi.org/10.1038/oby.2009.109

[16] Houston DK, Nicklas BJ, Ding J, Harris TB, Tylavsky FA, Newman $A B$, et al. Dietary protein intake is associated with lean mass change in older, community-dwelling adults: the Health, Aging, and Body Composition (Health ABC) Study. Am J Clin Nutr 2008; 87: 150-5. Reference: Available from: URL http://ajcn.nutrition.org/content/87/1/150.long

[17] Milne AC, Potter J, Vivanti A, Avenell A. Protein and energy supplementation in elderly people at risk from malnutrition. Cochrane Database Syst Rev 2009; 2: CD003288.

[18] Malafarina V, Uriz-Otano F, Iniesta R, Gil-Guerrero L. Effectiveness of nutritional supplementation on muscle mass in treatment of sarcopenia in old age: a systematic review. $J$ Am Med Dir Assoc 2013; 14: 10-7. http://dx.doi.org/10.1016/j.jamda.2012.08.001

[19] Biolo G, Ciocchi B, Stulle M, Bosutti A, Barazzoni R, Zanett $\mathrm{M}$, et al. Calorie restriction accelerates the catabolism of lean body mass during 2 wk of bed rest. Am J Clin Nutr 2007; 86: 366-72. Reference: Available from: URL http://ajcn.nutrition. org/content/86/2/366.long

[20] Wall BT, van Loon LJ. Nutritional strategies to attenuate muscle disuse atrophy. Nutr Rev 2013; 71: 195-208.

\section{http://dx.doi.org/10.1111/nure.12019}

[21] Wakabayashi $H$, Sashika $H$. Association of nutrition status and rehabilitation outcome in the disuse syndrome: $A$ retrospective cohort study. General Med 2011; 12: 69-74. Reference: Available from: URL http://www.jstage.jst.go.jp/ article/general/12/2/12_2_69/_pdf

[22] Kim HK, Suzuki T, Saito K, Yoshida H, Kobayashi H, Kato H, et al. Effects of exercise and amino acid supplementation on body composition and physical function in communitydwelling elderly Japanese sarcopenic women: a randomized controlled trial. J Am Geriatr Soc 2012; 60: 16-23. http://dx.doi.org/10.1111/j.1532-5415.2011.03776.x

[23] Cermak NM, Res PT, de Groot LC, Saris WH, van Loon LJ. Protein supplementation augments the adaptive response of skeletal muscle to resistance-type exercise training: a metaanalysis. Am J Clin Nutr 2012; 96: 1454-64.

http://dx.doi.org/10.3945/ajcn.112.037556

[24] Villareal DT, Chode S, Parimi N, Sinacore DR, Hilton T, Armamento-Villareal $\mathrm{R}$, et al. Weight loss, exercise, or both and physical function in obese older adults. $\mathrm{N}$ Engl $\mathrm{J}$ Med 2011; 364: 1218-29.

http://dx.doi.org/10.1056/NEJMoa1008234

[25] Douketis JD, Macie C, Thabane L, Williamson DF. Systematic review of long-term weight loss studies in obese adults: clinical significance and applicability to clinical practice. Int J Obes (Lond) 2005; 29: 1153-67. http://dx.doi.org/10.1038/sj.ijo.0802982

[26] Santos FL, Esteves SS, da Costa Pereira A, Yancy WS Jr, Nunes JP. Systematic review and meta-analysis of clinical trials of the effects of low carbohydrate diets on cardiovascular risk factors. Obes Rev 2012; 13: 1048-66. http://dx.doi.org/10.1111/j.1467-789X.2012.01021.x 
[27] Hooper L, Abdelhamid A, Moore HJ, Douthwaite W, Skeaff $\mathrm{CM}$, Summerbell CD. Effect of reducing total fat intake on body weight: systematic review and meta-analysis of randomised controlled trials and cohort studies. BMJ 2012; 345: e7666.

http://dx.doi.org/10.1136/bmi.e7666

[28] Nordmann AJ, Nordmann A, Briel M, Keller U, Yancy WS Jr, Brehm BJ, et al. Effects of low-carbohydrate vs low-fat diets on weight loss and cardiovascular risk factors: a metaanalysis of randomized controlled trials. Arch Intern Med 2006; 166: 285-93.

http://dx.doi.org/10.1001/archinte.166.3.285

[29] Hu T, Mills KT, Yao L, Demanelis K, Eloustaz M, Yancy WS $\mathrm{Jr}$, et al. Effects of low-carbohydrate diets versus low-fat diets on metabolic risk factors: a meta-analysis of randomized controlled clinical trials. Am J Epidemiol 2012; 176: S44-54. http://dx.doi.org/10.1093/aje/kws264

[30] Santesso N, AkI EA, Bianchi M, Mente A, Mustafa R, HeelsAnsdell $D$, et al. Effects of higher- versus lower-protein diets on health outcomes: a systematic review and meta-analysis. Eur J Clin Nutr 2012; 66: 780-8. Reference: Available from: URL http://www.ncbi.nlm.nih.gov/pmc/articles/PMC3392894/

[31] Wycherley TP, Moran LJ, Clifton PM, Noakes M, Brinkworth GD. Effects of energy-restricted high-protein, low-fat compared with standard-protein, low-fat diets: a metaanalysis of randomized controlled trials. Am J Clin Nutr 2012; 96: 1281-98.

http://dx.doi.org/10.3945/ajcn.112.044321

[32] Esposito K, Kastorini CM, Panagiotakos DB, Giugliano D. Mediterranean diet and weight loss: meta-analysis of randomized controlled trials. Metab Syndr Relat Disord 2011; 9: 1-12. http://dx.doi.org/10.1089/met.2010.0031

[33] Thomas DE, Elliott EJ, Baur L. Low glycaemic index or low glycaemic load diets for overweight and obesity. Cochrane Database Syst Rev 2007; 3: CD005105.

[34] Tsai AG, Wadden TA. The evolution of very-low-calorie diets: an update and meta-analysis. Obesity (Silver Spring) 2006; 14: 1283-93.

http://dx.doi.org/10.1038/oby.2006.146

[35] Wu T, Gao X, Chen M, van Dam RM. Long-term effectiveness of diet-plus-exercise interventions vs. diet-only interventions for weight loss: a meta-analysis. Obes Rev 2009; 10: 313-23.

http://dx.doi.org/10.1111/j.1467-789X.2008.00547.x

[36] Miyachi M, Ando D, Oida Y, Oguma Y, Ono R, Kitabatake $Y$, et al. Treatment indications for sarcopenia: a systematic review of exercise intervention effect. Nihon Ronen Igakkai Zasshi 2011; 48: 51-4. [Article in Japanese] Reference: Available from: URL http://www.jstage.jst.go.jp/article/ geriatrics/48/1/48_1_51/_pdf

[37] Peterson MD, Rhea MR, Sen A, Gordon PM. Resistance exercise for muscular strength in older adults: a metaanalysis. Ageing Res Rev 2010; 9: 226-37. Reference: Available from: URL http://www.ncbi.nlm.nih.gov/pmc/ articles/PMC2892859/

[38] Liu CJ, Latham NK. Progressive resistance strength training for improving physical function in older adults. Cochrane Database Syst Rev 2009; 3: CD002759.

[39] Ozaki H, Loenneke JP, Thiebaud RS, Stager JM, Abe T. Possibility of leg muscle hypertrophy by ambulation in older adults: a brief review. Clin Interv Aging 2013; 8: 369-75. http://dx.doi.org/10.2147/CIA.S43837

[40] Kodama S, Saito K, Tanaka S, Maki M, Yachi Y, Asumi M, et al. Cardiorespiratory fitness as a quantitative predictor of allcause mortality and cardiovascular events in healthy men and women: a meta-analysis. JAMA 2009; 301: 2024-35. http://dx.doi.org/10.1001/jama.2009.681
[41] Shaw K, Gennat H, O'Rourke P, Del Mar C. Exercise for overweight or obesity. Cochrane Database Syst Rev 2006; 4: CD003817.

[42] Thorogood A, Mottillo S, Shimony A, Filion KB, Joseph L, Genest J, et al. Isolated aerobic exercise and weight loss: a systematic review and meta-analysis of randomized controlled trials. Am J Med 2011; 124: 747-55. http://dx.doi.org/10.1016/j.amjmed.2011.02.037

[43] Richardson CR, Newton TL, Abraham JJ, Sen A, Jimbo M, Swartz AM. A meta-analysis of pedometer-based walking interventions and weight loss. Ann Fam Med 2008; 6: 69-77. http://dx.doi.org/10.1370/afm.761

[44] Strasser B, Siebert U, Schobersberger W. Resistance training in the treatment of the metabolic syndrome: a systematic review and meta-analysis of the effect of resistance training on metabolic clustering in patients with abnormal glucose metabolism. Sports Med 2010; 40: 397415.

\section{http://dx.doi.org/10.2165/11531380-000000000-00000}

[45] Dietz P, Hoffmann S, Lachtermann E, Simon P. Influence of exclusive resistance training on body composition and cardiovascular risk factors in overweight or obese children: a systematic review. Obes Facts 2012; 5: 546-60.

\section{http://dx.doi.org/10.1159/000341560}

[46] Ismail I, Keating SE, Baker MK, Johnson NA. A systematic review and meta-analysis of the effect of aerobic vs. resistance exercise training on visceral fat. Obes Rev 2012; 13: 68-91.

http://dx.doi.org/10.1111/j.1467-789X.2011.00931.x

[47] Ho SS, Dhaliwal SS, Hills AP, Pal S. The effect of 12 weeks of aerobic, resistance or combination exercise training on cardiovascular risk factors in the overweight and obese in a randomized trial. BMC Public Health 2012; 12: 704. http://dx.doi.org/10.1186/1471-2458-12-704

[48] Bhasin S, Calof OM, Storer TW, Lee ML, Mazer NA, Jasuja $\mathrm{R}$, et al. Drug insight: Testosterone and selective androgen receptor modulators as anabolic therapies for chronic illness and aging. Nat Clin Pract Endocrinol Metab 2006; 2: 146-59. Reference: Available from: URL http://www.ncbi.nlm.nih.gov/ pmc/articles/PMC2072878/

[49] Ottenbacher KJ, Ottenbacher ME, Ottenbacher AJ, Acha AA Ostir GV. Androgen treatment and muscle strength in elderly men: A meta-analysis. J Am Geriatr Soc 2006; 54: 1666-73. Reference: Available from: URL http://www.ncbi.nlm.nih.gov/ pmc/articles/PMC1752197/

[50] Fernández-Balsells MM, Murad MH, Lane MA, Lampropulos JF, Albuquerque F, Mullan RJ, et al. Adverse effects of testosterone therapy in adult men: a systematic review and meta-analysis. J Clin Endocrinol Metab 2010; 95: 2560-75. http://dx.doi.org/10.1210/jc.2009-2575

[51] Basaria S, Coviello AD, Travison TG, Storer TW, Farwell WR, Jette AM, et al. Adverse events associated with testosterone administration. N Engl J Med 2010; 363: 10922.

http://dx.doi.org/10.1056/NEJMoa1000485

[52] Liu H, Bravata DM, Olkin I, Nayak S, Roberts B, Garber AM, et al. Systematic review: the safety and efficacy of growth hormone in the healthy elderly. Ann Intern Med 2007; 146: 104-15.

http://dx.doi.org/10.7326/0003-4819-146-2-200701160$\underline{00005}$

[53] White HK, Petrie CD, Landschulz W, et al. Effects of an oral growth hormone secretagogue in older adults. J Clin Endocrinol Metab 2009; 94: 1198-206. http://dx.doi.org/10.1210/jc.2008-0632

[54] Giannoulis MG, Sonksen PH, Umpleby M, MacLean D, Taylor A, Lyles $\mathrm{K}$, et al. The effects of growth hormone and/or testosterone in healthy elderly men: a randomized controlled trial. J Clin Endocrinol Metab 2006; 91: 477-84. http://dx.doi.org/10.1210/jc.2008-0632 
[55] Giannoulis MG, Jackson N, Shojaee-Moradie F, Nair KS, Sonksen PH, Martin FC, et al. The effects of growth hormone and/or testosterone on whole body protein kinetics and skeletal muscle gene expression in healthy elderly men: a randomized controlled trial. J Clin Endocrinol Metab 2008; 93: 3066-74.

http://dx.doi.org/10.1210/jc.2007-2695

[56] Sattler FR, Castaneda-Sceppa C, Binder EF, Schroeder ET, Wang $\mathrm{Y}$, Bhasin S, et al. Testosterone and growth hormone improve body composition and muscle performance in older men. J Clin Endocrinol Metab 2009; 94: 1991-2001. http://dx.doi.org/10.1210/jc.2008-2338

[57] Schroeder ET, He J, Yarasheski KE, Binder EF, CastanedaSceppa C, Bhasin S, et al. Value of measuring muscle performance to assess changes in lean mass with testosterone and growth hormone supplementation. Eur $\mathrm{J}$ Appl Physiol 2012; 112: 1123-31. Reference: Available from: URL http://www.ncbi.nlm.nih.gov/pmc/articles/PMC3448487/

[58] Kojima M, Hosoda H, Date $Y$, Nakazato M, Matsuo H, Kangawa K. Ghrelin is a growth-hormone-releasing acylated peptide from stomach. Nature 1999; 402: 656-60.

http://dx.doi.org/10.1038/45230

[59] Nass R, Pezzoli SS, Oliveri MC, Patrie JT, Harrell FE Jr, Clasey JL, et al. Effects of an oral ghrelin mimetic on body composition and clinical outcomes in healthy older adults: a randomized trial. Ann Intern Med 2008; 149: 601-11. Reference: Available from: URL http://www.ncbi.nlm.nih.gov/ pmc/articles/PMC2757071/

[60] Akamizu T, Iwakura H, Ariyasu H, Murayama T, Sumi E, Teramukai $S$, et al. Effects of ghrelin treatment on patients undergoing total hip replacement for osteoarthritis: different outcomes from studies in patients with cardiac and pulmonary cachexia. J Am Geriatr Soc 2008; 56: 2363-5. http://dx.doi.org/10.1111/j.1532-5415.2008.02031.x

[61] Al-Said YA, Al-Rached HS, Al-Qahtani HA, Jan MM. Severe proximal myopathy with remarkable recovery after vitamin $\mathrm{D}$ treatment. Can J Neurol Sci 2009; 36: 336-9.

[62] Fabbriciani G, Pirro M, Leli C, Cecchetti A, Callarelli L, Rinonapoli G, et al. Diffuse muscoskeletal pain and proximal myopathy: do not forget hypovitaminosis D. J Clin Rheumatol 2010; 16: 34-7. http://dx.doi.org/10.1097/RHU.0b013e3181c3b2c0

[63] Houston DK, Neiberg RH, Tooze JA, Hausman DB, Johnson MA, Cauley JA, et al. Low 25-hydroxyvitamin D predicts the onset of mobility limitation and disability in communitydwelling older adults: The Health ABC Study. J Gerontol A Biol Sci Med Sci 2013; 68: 181-7.

http://dx.doi.org/10.1093/gerona/gls136

[64] Visser M, Deeg DJ, Lips P, Longitudinal Aging Study Amsterdam. Low vitamin D and high parathyroid hormone levels as determinants of loss of muscle strength and muscle mass (sarcopenia): the Longitudinal Aging Study Amsterdam. J Clin Endocrinol Metab 2003; 88: 5766-72. http://dx.doi.org/10.1210/jc.2003-030604

[65] Scott D, Blizzard L, Fell J, Ding C, Winzenberg T, Jones G. A prospective study of the associations between 25-hydroxyvitamin D, sarcopenia progression and physical activity in older adults. Clin Endocrinol (Oxf) 2010; 73: 581-7. http://dx.doi.org/10.1111/j.1365-2265.2010.03858.x

[66] Kim MK, Baek KH, Song KH, II Kang M, Park CY, Lee WY, et al. Vitamin $\mathrm{D}$ deficiency is associated with sarcopenia in older Koreans, regardless of obesity: the Fourth Korea National Health and Nutrition Examination Surveys (KNHANES IV) 2009. J Clin Endocrinol Metab 2011; 96: 3250-6.

http://dx.doi.org/10.1210/jc.2011-1602

[67] Seo JA, Cho H, Eun CR, Yoo HJ, Kim SG, Choi KM, et al. Association between visceral obesity and sarcopenia and vitamin $D$ deficiency in older Koreans: the Ansan Geriatric Study. J Am Geriatr Soc 2012; 60: 700-6.

http://dx.doi.org/10.1111/j.1532-5415.2012.03887.x
[68] Marantes I, Achenbach SJ, Atkinson EJ, Khosla S, Melton LJ 3rd, Amin S. Is vitamin $D$ a determinant of muscle mass and strength? J Bone Miner Res 2011; 26: 2860-71. Reference: Available from: URL http://www.ncbi.nlm.nih.gov/pmc/ articles/PMC3248226/

[69] Annweiler C, Schott AM, Berrut G, Fantino B, Beauchet O. Vitamin $D$-related changes in physical performance: a systematic review. J Nutr Health Aging 2009; 13: 893-8. http://dx.doi.org/10.1007/s12603-009-0248-x

[70] Stockton KA, Mengersen K, Paratz JD, Kandiah D, Bennell $\mathrm{KL}$. Effect of vitamin D supplementation on muscle strength: A systematic review and meta-analysis. Osteoporos Int 2011; 22: 859-71.

http://dx.doi.org/10.1007/s00198-010-1407-y

[71] Padwal R, Li SK, Lau DC. Long-term pharmacotherapy for obesity and overweight. Cochrane Database Syst Rev 2004; 3: CD004094.

[72] Rucker D, Padwal R, Li SK, Curioni C, Lau DC. Long term pharmacotherapy for obesity and overweight: updated metaanalysis. BMJ 2007; 335: 1194-9. http://dx.doi.org/10.1136/bmj.39385.413113.25

[73] Zhou YH, Ma XQ, Wu C, , Lu J, Zhang SS, Guo J, et al. Effect of anti-obesity drug on cardiovascular risk factors: a systematic review and meta-analysis of randomized controlled trials. PLoS One 2012; 7: e39062. http://dx.doi.org/10.1371/journal.pone.0039062

[74] Chan EW, He Y, Chui CS, Wong AY, Lau WC, Wong IC. Efficacy and safety of lorcaserin in obese adults: a metaanalysis of 1-year randomized controlled trials (RCTs) and narrative review on short-term RCTs. Obes Rev 2013. http://dx.doi.org/10.1111/obr.12015

[75] Gadde KM, Allison DB, Ryan DH, Peterson CA, Troupin B, Schwiers ML, et al. Effects of low-dose, controlled-release, phentermine plus topiramate combination on weight and associated comorbidities in overweight and obese adults (CONQUER): a randomised, placebo-controlled, phase 3 trial. Lancet 2011; 377: 1341-52.

http://dx.doi.org/10.1016/S0140-6736(11)60205-5

[76] Allison DB, Gadde KM, Garvey WT, Peterson CA, Schwiers ML, Najarian $\mathrm{T}$, et al. Controlled-release phentermine/topiramate in severely obese adults: a randomized controlled trial (EQUIP). Obesity (Silver Spring) 2012; 20: 330-42. Reference: Available from: URL http://www.ncbi.nlm.nih.gov/pmc/articles/PMC3270297/

[77] Garvey WT, Ryan DH, Look M, Gadde KM, Allison DB, Peterson CA, et al. Two-year sustained weight loss and metabolic benefits with controlled-release phentermine/ topiramate in obese and overweight adults (SEQUEL): a randomized, placebo-controlled, phase 3 extension study. Am J Clin Nutr 2012; 95: 297-308.

http://dx.doi.org/10.3945/ajcn.111.024927

[78] Smith SM, Meyer M, Trinkley KE. Phentermine/Topiramate for the treatment of obesity (March). Ann Pharmacother 2013; 47: 340-9. http://dx.doi.org/10.1345/aph.1R501

[79] Saneei P, Salehi-Abargouei A, Esmaillzadeh A. Serum 25hydroxy vitamin $D$ levels in relation to body mass index: a systematic review and meta-analysis. Obes Rev 2013; 14: 393-404.

http://dx.doi.org/10.1111/obr.12016

[80] Vimaleswaran KS, Berry DJ, Lu C, Tikkanen E, Pilz S, Hiraki $\mathrm{LT}$, et al. Causal relationship between obesity and vitamin $\mathrm{D}$ status: bi-directional mendelian randomization analysis of multiple cohorts. PLoS Med 2013; 10: e1001383. http://dx.doi.org/10.1371/journal.pmed.1001383

[81] Hwang B, Lim JY, Lee J, Choi NK, Ahn YO, Park BJ. Prevalence rate and associated factors of sarcopenic obesity in korean elderly population. J Korean Med Sci 2012; 27: 748-55.

http://dx.doi.org/10.3346/jkms.2012.27.7.748 
[82] Chung JY, Kang HT, Lee DC, Lee HR, Lee YJ. Body composition and its association with cardiometabolic risk factors in the elderly: a focus on sarcopenic obesity. Arch Gerontol Geriatr 2013; 56: 270-8.

http://dx.doi.org/10.1016/j.archger.2012.09.007

[83] Kim TN, Park MS, Lim KI, Choi HY, Yang SJ, Yoo HJ, et al. Relationships between sarcopenic obesity and insulin resistance, inflammation, and vitamin D status: the Korean Sarcopenic Obesity Study. Clin Endocrinol (Oxf) 2013; 78: 525-32.

http://dx.doi.org/10.1111/j.1365-2265.2012.04433.x

[84] Sneve M, Figenschau $Y$, Jorde $R$. Supplementation with cholecalciferol does not result in weight reduction in overweight and obese subjects. Eur J Endocrinol 2008; 159: 675-84.

http://dx.doi.org/10.1530/EJE-08-0339

[85] Zittermann A, Frisch S, Berthold HK, Götting C, Kuhn J, Kleesiek K, et al. Vitamin D supplementation enhances the beneficial effects of weight loss on cardiovascular disease risk markers. Am J Clin Nutr 2009; 89: 1321-7. http://dx.doi.org/10.3945/ajcn.2008.27004

[86] Salehpour A, Hosseinpanah F, Shidfar F, Vafa M, Razaghi $\mathrm{M}$, Dehghani $\mathrm{S}$, et al. A 12-week double-blind randomized clinical trial of vitamin $D_{3}$ supplementation on body fat mass in healthy overweight and obese women. Nutr $\mathrm{J} 2012 ; 11$ : 78.

http://dx.doi.org/10.1186/1475-2891-11-78

[87] Rosenblum JL, Castro VM, Moore CE, Kaplan LM. Calcium and vitamin D supplementation is associated with decreased abdominal visceral adipose tissue in overweight and obese adults. Am J Clin Nutr 2012; 95: 101-8.

http://dx.doi.org/10.3945/ajcn.111.019489

[88] Weinheimer EM, Sands LP, Campbell WW. A systematic review of the separate and combined effects of energy restriction and exercise on fat-free mass in middle-aged and older adults: implications for sarcopenic obesity. Nutr Rev 2010; 68: 375-88. http://dx.doi.org/10.1111/j.1753-4887.2010.00298.x

[89] Vincent HK, Raiser SN, Vincent KR. The aging musculoskeletal system and obesity-related considerations with exercise. Ageing Res Rev 2012; 11: 361-73. http://dx.doi.org/10.1016/..arr.2012.03.002

[90] Sakuma K, Yamaguchi A. Sarcopenic obesity and endocrinal adaptation with age. Int J Endocrinol 2013; 204164. http://dx.doi.org/10.1155/2013/204164

[91] Avenell A, Brown TJ, McGee MA, Campbell MK, Grant AM, Broom J, et al. What interventions should we add to weight reducing diets in adults with obesity? A systematic review of randomized controlled trials of adding drug therapy, exercise, behaviour therapy or combinations of these interventions. $\mathrm{J}$ Hum Nutr Diet 2004; 17: 293-316. http://dx.doi.org/10.1111/j.1365-277X.2004.00530.x

[92] Dixon JB, Strauss BJ, Laurie C, O'Brien PE. Changes in body composition with weight loss: obese subjects randomized to surgical and medical programs. Obesity (Silver Spring) 2007; 15: 1187-98. http://dx.doi.org/10.1038/oby.2007.639

Received on 24-05-2013

Accepted on 20-06-2013

Published on 30-06-2013

DOI: http://dx.doi.org/10.6000/1929-5634.2013.02.02.5

(C) 2013 Wakabayashi and Sakuma; Licensee Lifescience Global.

This is an open access article licensed under the terms of the Creative Commons Attribution Non-Commercial License (http://creativecommons.org/licenses/by-nc/3.0/) which permits unrestricted, non-commercial use, distribution and reproduction in any medium, provided the work is properly cited. 